\title{
An inventory of Canadian anesthesiology. Human research from 1995 through 1999
}

Roy E. Gagnon DT, Andrew J. Macnab MD FRCPC, Derek Blackstock MB FRCPC
Purpose: The year 2000 provides a symbolic opportunity to assess the past initiatives in anesthesia research. As in many other fields, medical research has benefited from utilizing computerized data bases to facilitate enumerating areas of interest. We have created a baseline survey of past research in the fields of anesthesia, anesthetics, analgesia, and analgesics to highlight Canadian studies.

Methods: The survey was undertaken using the Medical Literature Analysis and Retrieval System (MEDLARS) medical literature archive for the years 1995 through 1999. The principal categories and subcategories of MEDLARS' anesthesia classifications were counted for 70 countries contributing to the archive.

Results: Canadian contributions ranged from 141 (1992) to 185 (1999) and represented annually $3 \%$ of the world total in the anesthesia categories. The greatest number of studies (30-38\%) were about adults aged 19 to $44 \mathrm{yr}$, and there were between $4 \%$ and $14 \%$ more studies of females than males. "Pharmacology" and "therapeutic use" were the most frequent topics, lidocaine, fentanyl, and propofol were the most studied anesthetics, and nonsteroidal anti-inflammatories, opium, morphine, and fentanyl were the most studied analgesics. Among the types of studies, those classified as "quality of health care" occurred most frequently (16\%). Canadian trends closely follow world trends.

Conclusion: The collected counts provide a comprehensive overview of research trends for the past five years.

Objectif : L'an 2000 fournit un prétexte symbolique pour évaluer les initiatives passées en recherche anesthésique. Comme beaucoup d'autres champs de connaissances, la recherche médicale a bénéficié des bases de données informatisées qui facilitent le recensement des champs d'intérêt. Nous avons procédé à une enquête de base sur les recherches passées en anesthésie, sur les anesthésiques, l'analgésie et les analgésiques afin de faire ressortir les études canadiennes.

Méthode : L'enquête a été faite à partir des archives de la documentation médicale du Medical Literature Analysis and Retrieval System (MEDLARS) pour les années 1995 à 1999. Les principales catégories et sous-catégories des classifications anesthésiques de MEDLARS ont été dénombrées pour 70 pays qui contribuent aux archives.

Résultats : Les contributions canadiennes vont de 141 (1992) à 185 (1999) et représentent annuellement $3 \%$ du total mondial dans les catégories anesthésiques. Le plus grand nombre (30-38\%) comprenait des adultes de 19 à 44 ans; il y a eu entre $4 \%$ et $14 \%$ plus d'études sur les femmes que sur les hommes. "La pharmacologie" et "l'usage thérapeutique" sont les sujets les plus fréquents; la lidocaine, le fentanyl et le propofol sont les anesthésiques les plus testés; les anti-inflammatoires non stérödiens, l'opium, la morphine et le fentanyl sont les analgésiques les plus étudiés. Parmi les types d'études, celles qui portent sur la "qualité des soins de santé" sont les plus nombreuses (16\%). Les orientations canadiennes sont celles du reste du monde.

Conclusion : Les dénombrements recueillis fournissent une vie d'ensemble détallée des tendances de la recherche pour les cinq dernières années.

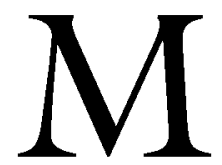
EDICAL research has long benefited from the availability of computerized data bases to enumerate areas of interest. One of the world's largest databases, the Medical Literature Analysis and Retrieval System (MEDLARS) is part of the National Library of Medicine (Bethesda, MD, USA) archive. MEDLARS now (March 2001) has almost 11 million entries in its database and can be accessed free of charge through the Internet via its web site at: www.ncbi.nlm.nih.gov/PubMed. This allows medical researchers around the world to cite related works, compile a current state-of-knowledge, and benefit from having their own works be made universally available.

Since 1987, articles archived in MEDLARS have been catalogued with the author's affiliation address. This feature allows retrieving and counting of articles having a specific content in conjunction with specific countries, cities, or institutions.

From the Departments of Paediatrics and Anaesthesia, Children's \& Women's Health Centre of British Columbia, Vancouver, British Columbia, Canada.

Address correspondence to. Dr. Andrew Macnab, Critical Care Research Office, Room L317, Mail Box 80, Children's \& Women's Health Centre of British Columbia, 4480 Oak Street, Vancouver, British Columbia, V6H 3V4, Canada. Phone: 604-875-3524; Fax: 604263-5031; E-mail: regagnon $@$ interchange.ubc.ca

Accepted for publication January 16, 2001. 
TABLE I International counts of original human research from major sub-categories archived in MEDLARS from 1995 through 1999

\begin{tabular}{|c|c|c|c|}
\hline Search terms & $\begin{array}{l}\text { Canada } \\
\text { total }\end{array}$ & $\begin{array}{l}\text { World } \\
\text { total }\end{array}$ & $\begin{array}{l}\text { Canada \% } \\
\text { of world }\end{array}$ \\
\hline Anesthetics & 264 & 9,019 & $3 \%$ \\
\hline Anesthetics, combined & 12 & 234 & $5 \%$ \\
\hline Anesthetics, dissociative & 6 & 292 & $2 \%$ \\
\hline Anesthetics, general & 147 & 4,820 & $3 \%$ \\
\hline Anesthetics, inhalation & 58 & 1,926 & $3 \%$ \\
\hline Anesthetics, intravenous & 110 & 3,350 & $3 \%$ \\
\hline Anesthetics, local & 121 & 4,214 & $3 \%$ \\
\hline Anesthesia & 220 & 7,379 & $3 \%$ \\
\hline Acupuncture anesthesia & 0 & 18 & $0 \%$ \\
\hline Anesthesia, conduction & 97 & 3,175 & $3 \%$ \\
\hline Anesthesia, caudal & 3 & 41 & $7 \%$ \\
\hline Anesthesia, epidural & 24 & 722 & $3 \%$ \\
\hline Anesthesia, local & 22 & 1,006 & $2 \%$ \\
\hline Conduction, nerve block & 52 & 1,047 & $5 \%$ \\
\hline $\begin{array}{l}\text { Conduction, autonomic } \\
\text { nerve block }\end{array}$ & 9 & 156 & $6 \%$ \\
\hline Anesthesia, spinal & 22 & 674 & $3 \%$ \\
\hline Anesthesia, dental & 7 & 405 & $2 \%$ \\
\hline Anesthesia, hypnosis, dental & 0 & 12 & $0 \%$ \\
\hline Anesthesia, general & 78 & 2,653 & $3 \%$ \\
\hline Anesthesia, inhalation & 26 & 783 & $3 \%$ \\
\hline Anesthesia, closed-circuit & 2 & 94 & $2 \%$ \\
\hline Anesthesia, rectal & 0 & 1 & $0 \%$ \\
\hline Anesthesia, intratracheal & 0 & 43 & $0 \%$ \\
\hline Anesthesia, intravenous & 24 & 571 & $4 \%$ \\
\hline Anesthesia, obstetrical & 16 & 363 & $4 \%$ \\
\hline Electroacupuncture & 1 & 75 & $1 \%$ \\
\hline Hypnosis, anesthetic & 0 & 26 & $0 \%$ \\
\hline Analgesics & 550 & 16,911 & $3 \%$ \\
\hline Analgesics non-narcotic & 318 & 10,172 & $3 \%$ \\
\hline Analgesics opioid & 147 & 4,321 & $3 \%$ \\
\hline Analgesia & 79 & 2,110 & $4 \%$ \\
\hline Acupuncture analgesia & 0 & 32 & $0 \%$ \\
\hline Analgesia, epidural & 23 & 678 & $3 \%$ \\
\hline Analgesia, obstetrical & 13 & 359 & $4 \%$ \\
\hline Analgesia, patient-controlled & 29 & 491 & $6 \%$ \\
\hline $\begin{array}{l}\text { Audioanalgesia } \\
\text { (last reported in 1991) }\end{array}$ & 0 & 0 & - \\
\hline Electroacupuncture & 1 & 75 & $1 \%$ \\
\hline Neuroleptanalgesia & 2 & 33 & $6 \%$ \\
\hline $\begin{array}{l}\text { Transcutaneous electric } \\
\text { nerve stimulation }\end{array}$ & 10 & 240 & $4 \%$ \\
\hline Anesthesia and analgesia & 328 & 10,187 & $3 \%$ \\
\hline Anesthesiology & 20 & 831 & $2 \%$ \\
\hline
\end{tabular}

MEDLARS has an extensive quality control process to scrutinize and codify the submissions from its 3,900 contributing journals. The journals themselves must meet certain requirements (Index Medicus) before being eligible for inclusion in the archive. The code system medical subject headings (MESH) used to describe any particular article is standardized and has been updated and enlarged by committee consen-
TABLE II Canadian counts of original human research from topic sub-categories archived in MEDLARS from 1995 through 1999 corresponding to Table I

\begin{tabular}{|c|c|c|c|c|}
\hline Topic subheadings & $\begin{array}{l}\text { Anesthetics } \\
\text { total }\end{array}$ & $\begin{array}{l}\text { Anesthesia } \\
\text { total }\end{array}$ & $\begin{array}{l}\text { Analgesics } \\
\text { total }\end{array}$ & $\begin{array}{l}\text { Analgesia } \\
\text { total }\end{array}$ \\
\hline Pharmacology & 223 & 135 & 522 & 53 \\
\hline Therapeutic use & 172 & 128 & 451 & 56 \\
\hline Therapy & 110 & 96 & 357 & 63 \\
\hline $\begin{array}{l}\text { Physiology } \\
\text { Administration }\end{array}$ & 120 & 74 & 366 & 22 \\
\hline and dosage & 117 & 71 & 216 & 38 \\
\hline Adverse effects & 78 & 64 & 185 & 22 \\
\hline Drug effects & 110 & 54 & 223 & 16 \\
\hline Methods & 53 & 57 & 75 & 32 \\
\hline Metabolism & 82 & 38 & 267 & 8 \\
\hline Analysis & 49 & 30 & 125 & 6 \\
\hline Surgery & 38 & 50 & 50 & 18 \\
\hline Blood & 37 & 20 & 75 & 6 \\
\hline Chemistry & 26 & 9 & 135 & 5 \\
\hline Pharmacokinetics & 24 & 9 & 67 & 4 \\
\hline $\begin{array}{l}\text { Analogs and derivatives } \\
\text { Statistics and }\end{array}$ & 18 & 7 & 68 & 4 \\
\hline numerical data & 10 & 9 & 44 & 3 \\
\hline Instrumentation & 7 & 13 & 6 & 6 \\
\hline Epidemiology & 9 & 6 & 35 & 1 \\
\hline Psychology & 4 & 5 & 23 & 3 \\
\hline Diagnostic use & 9 & 2 & 14 & 1 \\
\hline Standards & 3 & 3 & 8 & 4 \\
\hline Economics & 2 & 6 & 8 & 2 \\
\hline Urine & 5 & 1 & 26 & 0 \\
\hline \multicolumn{5}{|l|}{ Antagonists and } \\
\hline inhibitors & 4 & 0 & 49 & 1 \\
\hline Nursing & 0 & 2 & 9 & 4 \\
\hline Toxicity & 5 & 1 & 19 & 0 \\
\hline Biosynthesis & 2 & 1 & 31 & 0 \\
\hline Classification & 0 & 1 & 9 & 0 \\
\hline Immunology & 1 & 0 & 21 & 0 \\
\hline Trends & 0 & 1 & 6 & 1 \\
\hline Education & 1 & 4 & 4 & 0 \\
\hline Mortality & 2 & 0 & 8 & 0 \\
\hline History & 0 & 2 & 1 & 1 \\
\hline Chemical synthesis & 1 & 0 & 6 & 0 \\
\hline Isolation and purification & 0 & 0 & 8 & 0 \\
\hline Cerebrospinal fluid & 1 & 1 & 1 & 0 \\
\hline Utilization & 0 & 0 & 4 & 2 \\
\hline Agonists & 0 & 0 & 6 & 0 \\
\hline Poisoning & 0 & 0 & 4 & 0 \\
\hline Contraindications & 0 & 1 & 0 & 0 \\
\hline Radiation effects & 0 & 0 & 4 & 0 \\
\hline Supply and distribution & 0 & 0 & 1 & 0 \\
\hline Manpower & 0 & 0 & 0 & 0 \\
\hline
\end{tabular}

sus to keep it consistent with current topics. Combined, the standardized coding, quality control system, and restricted input imply that MEDLARS retrieval counts will reliably indicate patterns of change in research reporting.

We investigated the publication record of Canadian research reports archived in MEDLARS with respect 
TABLE III Canadian counts of original human research regarding anesthesia, analgesia, anesthetics, and anesthesia from cities and universities as archived in MEDLARS from 1995 through 1999

\begin{tabular}{lll}
\hline Location & $1995-1999$ Canada total & $\%$ of Canada \\
\hline Vancouver & 86 & $10 \%$ \\
Victoria & 13 & $2 \%$ \\
Edmonton & 77 & $9 \%$ \\
Calgary & 43 & $5 \%$ \\
Saskatoon & 16 & $2 \%$ \\
Winnipeg & 42 & $5 \%$ \\
Toronto & 272 & $32 \%$ \\
Ottawa & 65 & $8 \%$ \\
Hamilton & 25 & $3 \%$ \\
London & 48 & $6 \%$ \\
Montreal & 128 & $15 \%$ \\
Halifax & 34 & $4 \%$ \\
& & \\
U British Columbia & 61 & $7 \%$ \\
U Alberta & 88 & $10 \%$ \\
U Calgary & 30 & $4 \%$ \\
U Saskatchewan & 17 & $2 \%$ \\
U Manitoba & 36 & $4 \%$ \\
U Toronto & 159 & $19 \%$ \\
U Western Ontario & 46 & $5 \%$ \\
McMaster U & 31 & $4 \%$ \\
Queen's U & 13 & $2 \%$ \\
McGill U & 55 & $6 \%$ \\
Laval U & 21 & $2 \%$ \\
Dalhousie U & 20 & $2 \%$ \\
Memorial U & 5 & $1 \%$ \\
\hline
\end{tabular}

to anesthesiology, anesthetics, anesthesia, analgesics, and analgesia for the years 1995 through 1999.

Methods

The "Advanced Search" utility of the PubMed web site was used to search MEDLARS using the MEDLINE field codes for address "[ad]", date published "[dp]", publication type "[pt]", major heading "[mh]" and subheading "[sh]".

Only articles coded as "human[mh]" were counted; thus human studies containing an animal component were also included.

Five principal categories were investigated separately and as combined totals using the expression "AND (anesthesiology [mh] OR anesthetics[mh] OR anesthesia[mh] OR analgesics[mh] OR analgesia[mh])", as well as the diphthong variants. Similarly, the years 1995 through 1999 were counted using the expression "AND (1995[dp] OR 1996[dp] OR 1997[dp] OR 1998[dp] OR 1999[dp])".

Since we wanted to count only articles having original research, we excluded other types of publications by using the expression "NOT (case reports[mh] OR letter[pt] OR editorial[pt] OR comment[pt] OR
TABLE IV International counts of original human research regarding anesthesia, analgesia, anesthetics, and anesthesia types of studies as archived in MEDLARS from 1995 through 1999

\begin{tabular}{|c|c|c|c|}
\hline Evaluation studies & $\begin{array}{l}\text { Canada } \\
\text { total }\end{array}$ & $\begin{array}{l}\text { World } \\
\text { total }\end{array}$ & $\begin{array}{l}\text { Canada \% } \\
\text { of world }\end{array}$ \\
\hline $\begin{array}{l}\text { Adverse drug reaction } \\
\text { reporting systems }\end{array}$ & 2 & 36 & $6 \%$ \\
\hline Case study & 0 & 0 & - \\
\hline Clinical trials & 20 & 330 & $6 \%$ \\
\hline Clinical trials, phase I & 0 & 1 & $0 \%$ \\
\hline Clinical trials, phase II & 0 & 5 & $0 \%$ \\
\hline Clinical trials, phase III & 0 & 8 & $0 \%$ \\
\hline Clinical trials, phase IV & 0 & 0 & - \\
\hline Cohort study & 168 & 4,284 & $4 \%$ \\
\hline Comparative study & 230 & 6,603 & $3 \%$ \\
\hline Computer simulation & 2 & 110 & $2 \%$ \\
\hline Controlled clinical trials & 0 & 17 & $0 \%$ \\
\hline Cross-over studies & 40 & 812 & $5 \%$ \\
\hline Device approval & 0 & 2 & $0 \%$ \\
\hline Drug approval & 3 & 186 & $2 \%$ \\
\hline Drug evaluation & 2 & 88 & $2 \%$ \\
\hline Drug screening & 1 & 86 & $1 \%$ \\
\hline Epidemiologic study & 213 & 5,754 & $4 \%$ \\
\hline Evaluation study & 46 & 1,507 & $3 \%$ \\
\hline Evaluation study, drug & 2 & 88 & $2 \%$ \\
\hline $\begin{array}{l}\text { Health care } \\
\text { evaluation mechanisms }\end{array}$ & 459 & 12,997 & $4 \%$ \\
\hline Incidence & 21 & 523 & $4 \%$ \\
\hline Interdisciplinary study & 194 & 4,583 & $4 \%$ \\
\hline Intervention study & 0 & 12 & $0 \%$ \\
\hline $\begin{array}{l}\text { Investigational new } \\
\text { drug application }\end{array}$ & 0 & 1 & $0 \%$ \\
\hline Longitudinal study & 159 & 4,097 & $4 \%$ \\
\hline Medical futility & 0 & 1 & $0 \%$ \\
\hline Methodological study & 0 & 29 & $0 \%$ \\
\hline Multicenter studies & 1 & 29 & $3 \%$ \\
\hline $\begin{array}{l}\text { Outcome and process } \\
\text { assessment \{health care }\end{array}$ & 78 & 2,284 & $3 \%$ \\
\hline $\begin{array}{l}\text { Outcome assessment } \\
\text { \{health care\} }\end{array}$ & 77 & 2,253 & $3 \%$ \\
\hline Outcome study & 77 & 2,253 & $3 \%$ \\
\hline Pain measurement & 85 & 1,774 & $5 \%$ \\
\hline $\begin{array}{l}\text { Product surveillance, } \\
\text { postmarketing }\end{array}$ & 2 & 58 & $3 \%$ \\
\hline Program evaluation & 1 & 58 & $2 \%$ \\
\hline Prospective studies & 123 & 2,962 & $4 \%$ \\
\hline Quality of health care & 468 & 13,489 & $3 \%$ \\
\hline Questionnaires & 22 & 619 & $4 \%$ \\
\hline $\begin{array}{l}\text { Randomized controlled } \\
\text { trials }\end{array}$ & 17 & 195 & $9 \%$ \\
\hline Reference values & 8 & 380 & $2 \%$ \\
\hline Reproducibility of results & 20 & 571 & $4 \%$ \\
\hline Retrospective studies & 48 & 1,374 & $3 \%$ \\
\hline Sampling study & 1 & 29 & $3 \%$ \\
\hline Statistical study & 132 & 4,000 & $3 \%$ \\
\hline Study, case-base & 57 & 1,730 & $3 \%$ \\
\hline Study, feasibility & 6 & 147 & $4 \%$ \\
\hline Study, follow-up & 53 & 1,284 & $4 \%$ \\
\hline Study, pilot & 12 & 314 & $4 \%$ \\
\hline Study, prevalence & 6 & 155 & $4 \%$ \\
\hline Study, seroepidemiologic & 0 & 11 & $0 \%$ \\
\hline Study, single-blind & 14 & 381 & $4 \%$ \\
\hline Study, theoretical & 26 & 879 & $3 \%$ \\
\hline Study, time & 0 & 5 & $0 \%$ \\
\hline Study, transcultural & 0 & 23 & $0 \%$ \\
\hline Time factors & 82 & 2,303 & $4 \%$ \\
\hline Treatment failure & 4 & 91 & $4 \%$ \\
\hline Treatment outcome & 73 & 2,161 & $3 \%$ \\
\hline
\end{tabular}


TABLE V Counts of original human research regarding local anesthetics as archived in MEDLARS from 1995 through 1999

\begin{tabular}{llll}
\hline Anesthetics, local & $\begin{array}{l}\text { 1995-1999 } \\
\text { Canada total }\end{array}$ & $\begin{array}{l}\text { 1995-1999 } \\
\text { World total }\end{array}$ & $\begin{array}{l}\text { Canada } \\
\% \text { of world }\end{array}$ \\
\hline Benzocaine & 2 & 33 & $6 \%$ \\
Benzyl alcohol & 2 & 11 & $18 \%$ \\
Bupivacaine & 26 & 993 & $3 \%$ \\
Carticaine & 0 & 22 & $0 \%$ \\
Cocaine & 21 & 1,239 & $2 \%$ \\
Dibucaine & 0 & 23 & $0 \%$ \\
Diphenhydramine & 4 & 88 & $5 \%$ \\
Ethyl chloride & 0 & 7 & $0 \%$ \\
Etidocaine & 0 & 6 & $0 \%$ \\
Lidocaine & 52 & 1,384 & $4 \%$ \\
Mepivacaine & 1 & 139 & $1 \%$ \\
Phenazopyridine & 0 & 3 & $0 \%$ \\
Prilocaine & 17 & 221 & $8 \%$ \\
Procaine & 3 & 119 & $3 \%$ \\
Propoxycaine & 1 & 15 & $7 \%$ \\
Tetracaine & 5 & 110 & $5 \%$ \\
Trimecaine & 0 & 5 & $0 \%$ \\
\hline
\end{tabular}

TABLE VI Counts of original human research regarding inhalation anesthetics as archived in MEDLARS from 1995 through 1999

\begin{tabular}{llll}
\hline Anesthetics, inhalation & $\begin{array}{l}\text { 1995-1999 } \\
\text { Canada total }\end{array}$ & $\begin{array}{l}\text { 1995-1999 } \\
\text { World total }\end{array}$ & $\begin{array}{l}\text { Canada \% } \\
\text { of porld }\end{array}$ \\
\hline Enflurane & 4 & 95 & $4 \%$ \\
Ether, ethyl & 0 & 63 & $0 \%$ \\
Halothane & 21 & 371 & $6 \%$ \\
Isoflurane & 17 & 732 & $2 \%$ \\
Methoxyflurane & 0 & 4 & $0 \%$ \\
Nitrous oxide & 19 & 600 & $3 \%$ \\
Trichloroethylene & 3 & 68 & $4 \%$ \\
Xenon & 2 & 106 & $2 \%$ \\
\hline
\end{tabular}

review[pt] OR review tutorial[pt] OR practice guidelines[pt])".

Wherever possible Canadian counts were compared with world wide counts. World counts were obtained using the same inclusion and exclusion expressions as used for the Canadian counts, except that the term "Canada[ad]" was omitted. Therefore, world counts, by default, contain the archives of 70 contributing countries including those from Canada.

We counted anesthesia, anesthetic, analgesia, analgesic, anesthesiology, and their diphthong variants, combined with respect to major Canadian cities, medical schools, international journals, types of publications, test subject's age, and, test subject's gender.

To compare the research output of anesthesiologists $v s$ other clinical specialties we counted the original Canadian research articles from 1988 through
TABLE VII Counts of original human research regarding $i p$ anesthetics as archived in MEDLARS from 1995 through 1999

\begin{tabular}{llll}
\hline Anesthetics, ip & $\begin{array}{l}1995-1999 \\
\text { Canada total }\end{array}$ & $\begin{array}{l}\text { 1995-1999 } \\
\text { World total }\end{array}$ & $\begin{array}{l}\text { Canada\% } \\
\text { of world }\end{array}$ \\
\hline Alfentanil & 11 & 241 & $5 \%$ \\
Ketamine & 6 & 292 & $2 \%$ \\
Tiletamine & 0 & 0 & - \\
Chloral hydrate & 1 & 56 & $2 \%$ \\
Chloralose & 0 & 2 & $0 \%$ \\
Diazepam & 6 & 432 & $1 \%$ \\
Etomidate & 0 & 80 & $0 \%$ \\
Fentanyl & 52 & 1,166 & $4 \%$ \\
Methohexital & 2 & 60 & $3 \%$ \\
Midazolam & 27 & 678 & $4 \%$ \\
Propanidid & 0 & 2 & $0 \%$ \\
Propofol & 45 & 1,072 & $4 \%$ \\
Sodium oxybate & 0 & 34 & $0 \%$ \\
Sufentanil & 9 & 201 & $4 \%$ \\
Thiamylal & 0 & 22 & $0 \%$ \\
Thiopental & 12 & 282 & $4 \%$ \\
Urethane & 1 & 26 & $4 \%$ \\
\hline
\end{tabular}

TABLE VIII Counts of original human research regarding anal gesics as archived in MEDLARS from 1995 through 1999

\begin{tabular}{llll}
\hline Analgesics & $\begin{array}{l}\text { 1995-1999 } \\
\text { Canada total }\end{array}$ & $\begin{array}{l}\text { 1995-1999 } \\
\text { World total }\end{array}$ & $\begin{array}{l}\text { Canada \% } \\
\text { of world }\end{array}$ \\
\hline Adenosine & 41 & 944 & $4 \%$ \\
Clonidine & 16 & 605 & $3 \%$ \\
Ketamine & 6 & 292 & $2 \%$ \\
Magnesium sulfate & 4 & 224 & $2 \%$ \\
Mitoxantrone & 15 & 422 & $4 \%$ \\
\hline
\end{tabular}

1998 made by those specialties as listed by the Royal College of Physician and Surgeons of Canada.

Results

There were 1,842 data counts obtained from five principal categories, 22 major categories and 421 subcategories.

The total annual Canadian output of original research articles in the combined principal categories of anesthesia, anesthetics, analgesia, analgesics, and anesthesiology ranged from 141 (1992) to 185 (1999) and represented annually $3 \%$ of the world total in those categories.

The five-year survey (1995-1999) of test subjects' gender showed an equal distribution between sexes in the analgesic studies. There were $4 \%$ more females than males in the study of anesthetics, $7 \%$ more females in the study of anesthesia, and 14\% more females in the analgesia studies. 
TABLE IX Counts of original human research regarding nonnarcotic analgesics as archived in MEDLARS from 1995 through 1999

\begin{tabular}{llll}
\hline $\begin{array}{l}\text { Analgesics, } \\
\text { non-narcotic }\end{array}$ & $\begin{array}{l}\text { 1995-1999 } \\
\text { Canada total }\end{array}$ & $\begin{array}{l}\text { 1995-1999 } \\
\text { World total }\end{array}$ & $\begin{array}{l}\text { Canada \% } \\
\text { of world }\end{array}$ \\
\hline Acetaminophen & 30 & 652 & $5 \%$ \\
Amantadine & 7 & 97 & $7 \%$ \\
Amitriptyline & 5 & 226 & $2 \%$ \\
Anti-inflammatory & 191 & 6,557 & $3 \%$ \\
agents, non-steroidal & & & \\
Carbachol & 16 & 419 & $4 \%$ \\
Carbamazepine & 16 & 503 & $3 \%$ \\
Cimetidine & 7 & 276 & $3 \%$ \\
Clodronic acid & 2 & 91 & $2 \%$ \\
Cyclazocine & 0 & 1 & $0 \%$ \\
Dexmedetomidine & 0 & 1 & $0 \%$ \\
Dihydroergotamine & 3 & 41 & $7 \%$ \\
Dimethyl sulfoxide & 18 & 412 & $4 \%$ \\
Ergotamine & 5 & 69 & $7 \%$ \\
Glafenine & 0 & 0 & - \\
Medetomidine & 0 & 0 & - \\
Methotrimeprazine & 0 & 8 & $0 \%$ \\
Nefopam & 0 & 7 & $0 \%$ \\
Nitrous oxide & 19 & 600 & $3 \%$ \\
Phenacetin & 1 & 39 & $3 \%$ \\
Pizotyline & 0 & 5 & $0 \%$ \\
Quinine & 8 & 257 & $3 \%$ \\
Tetrahydrocannabinol & 2 & 133 & $2 \%$ \\
U-50488 & 0 & 9 & $0 \%$ \\
\hline & & & \\
\hline
\end{tabular}

In all principal categories there were no studies anywhere in the world with test subjects greater than 80 yr of age. In Canada, between $30 \%$ and $38 \%$ of the studies in each principal category involved adults aged 19 to $44 \mathrm{yr}$. The next greatest age group in all categories was middle-aged (45-64 yr), and it was in 18\% to $21 \%$ of the studies. The third greatest age group involved, and once again this was true for each principal category, were children aged six to $12 \mathrm{yr}$; and they were involved in either $12 \%$ or $17 \%$ of the studies, depending upon category.

Among the ten publication types, in Canada, "Journal Article"(s) had the greatest number of publications in each of the principal categories and accounted for $45 \%$ to $58 \%$ of the total output. "Clinical Trial"(s) and "Randomized Controlled Trials" were the next most predominant publications with between $13 \%$ and $26 \%$ of the output depending upon the principal category.

Most original research by Canadians was published in the "Canadian Journal of Anesthesia", which represented $45 \%$ of the Canadian total for the principal categories counted from 19 international journals. The journal, "Anesthesia and Analgesia" was the next great-
TABLE X Counts of original human research regarding opioid analgesics as archived in MEDLARS from 1995 through 1999

\begin{tabular}{|c|c|c|c|}
\hline Analgesics, opioid & $\begin{array}{l}\text { 1995-1999 } \\
\text { Canada total }\end{array}$ & $\begin{array}{l}\text { 1995-1999 } \\
\text { World total }\end{array}$ & $\begin{array}{l}\text { Canada \% } \\
\text { of world }\end{array}$ \\
\hline Alfentanil & 11 & 241 & $5 \%$ \\
\hline Alphaprodine & 0 & 0 & - \\
\hline Buprenorphine & 0 & 174 & $0 \%$ \\
\hline Butorphanol & 1 & 47 & $2 \%$ \\
\hline Codeine & 22 & 287 & $8 \%$ \\
\hline Dextromoramide & 0 & 6 & $0 \%$ \\
\hline Dihydromorphine & 0 & 8 & $0 \%$ \\
\hline Enkephalin, & 0 & 1 & $0 \%$ \\
\hline $\mathrm{Ala}(2)-\mathrm{MePhe}(4)-\mathrm{Gly}(5)-$ & & & \\
\hline Enkephalin, & 0 & 2 & $0 \%$ \\
\hline D-Penicillamine $(2,5)$ - & & & \\
\hline Ethylketocyclazocine & 0 & 8 & $0 \%$ \\
\hline Ethylmorphine & 0 & 9 & $0 \%$ \\
\hline Etorphine & 0 & 30 & $0 \%$ \\
\hline Fentanyl & 52 & 1,166 & $4 \%$ \\
\hline Heroin & 1 & 243 & $0 \%$ \\
\hline Hydrocodone & 2 & 19 & $11 \%$ \\
\hline Hydromorphone & 9 & 54 & $17 \%$ \\
\hline Levorphanol & 1 & 19 & $5 \%$ \\
\hline Meperidine & 5 & 260 & $2 \%$ \\
\hline Meptazinol & 0 & 1 & $0 \%$ \\
\hline Methadone & 9 & 629 & $1 \%$ \\
\hline Methadyl acetate & 0 & 14 & $0 \%$ \\
\hline Morphine & 76 & 1,654 & $5 \%$ \\
\hline Nalbuphine & 0 & 55 & $0 \%$ \\
\hline Opium & 76 & 1,995 & $4 \%$ \\
\hline Oxycodone & 6 & 55 & $11 \%$ \\
\hline Oxymorphone & 1 & 7 & $14 \%$ \\
\hline Pentazocine & 0 & 37 & $0 \%$ \\
\hline Phenazocine & 0 & 2 & $0 \%$ \\
\hline Phenoperidine & 0 & 1 & $0 \%$ \\
\hline Pirinitramide & 0 & 31 & $0 \%$ \\
\hline Promedol & 0 & 6 & $0 \%$ \\
\hline Propoxyphene & 0 & 41 & $0 \%$ \\
\hline Sufentanil & 9 & 201 & $4 \%$ \\
\hline Tilidine & 0 & 9 & $0 \%$ \\
\hline Tramadol & 0 & 153 & $0 \%$ \\
\hline
\end{tabular}

est source of Canadian publications with $18 \%$ of the Canadian total. By comparison "Anesthesia and Analgesia" had the greatest proportion of the world totals (i.e., 20\%), and "Canadian Journal of Anesthesia" had the fifth greatest total world wide $(8 \%)$.

Across Canada, among 12 cities and 13 universities, most of the original research publications in the principal categories, came from affiliations in Toronto (32\% of Canadian total) and the University of Toronto with $19 \%$ of the Canadian total. These were followed by Montreal (15\%), Vancouver (10\%), and the University of Alberta (10\%).

Each of the principal categories, "anesthetic", "anesthesia", "analgesic", "analgesia", has 43 subcategories 
such as "adverse effects", "diagnostic use", "metabolism", "urine". In the Canadian original articles, "pharmacology" was the greatest subcategory (14-17\%) in each principal category. "Therapeutic use" was the second greatest subcategory in each principal category (13-15\%). These placings were also the same world wide.

Seventeen local anesthetics were counted and among these "lidocaine" had the greatest number (39\%) of Canadian original research publications. This was also true among all the countries world wide (31\%).

Seventeen iv anesthetics were also counted, and among these "fentanyl" had the greatest number (30\%) and "propofol" the second greatest $(26 \%)$ of Canadian original research publications, and again this was true world wide ( 25 and $23 \%$ respectively).

Twenty-three non-narcotic analgesics were counted, and among them the broad category of "antiinflammatory agents, non-steroidal" had by far the greatest number (64\%) of Canadian original research articles. The next greatest count $(10 \%)$ was from "acetaminophen". Again, this was also true world wide ( 70 and $7 \%$ respectively).

Thirty-five analgesic opiates were counted and among these "morphine" and "opium" were tied for the greatest Canadian count (27\%) of original research articles. "Fentanyl" was the next greatest Canadian count $(19 \%)$. World wide, "opium" was first $(27 \%)$, "morphine" second (22\%), and "fentanyl" third (16\%).

When all of the principal categories combined were counted with respect to 59 study types (e.g., "clinical trial", "intervention study", "prospective study" etc.), those coded "quality of health care" had the greatest Canadian (15\%) and greatest world wide (16\%) count of original research articles.

When the categories of "anesthetics", "anesthesia", "analgesics", "analgesia", "anesthesia and analgesia", "anesthesiology", and their diphthong variants there were 916 Canadian publications and 30,009 publications world wide. When this same search strategy was appended to the list of 19 anesthesiology journals there were 263 Canadian publications and 5,431 publications world wide. Thus, only $28.7 \%$ of Canadian anesthesiology publications were found in anesthesiology journals, compared with $18.1 \%$ world wide.

\section{Discussion}

One of the most important benefits of having an inventory of current research trends is its potential to confirm whether a balanced point of view has occurred. We believe ours is a complete survey of the MEDLARS anesthesiology contents from 1995 through 1998, and is within $96 \%$ complete for the year 1999 . At the time the survey was compiled in mid 2000 not all publisher's had completed their submissions to the archive. It is not an entire survey of anesthesiology publications since not all sources are archived in MEDLARS. New journals, non-peer reviewed articles, and text books are not archived, and only those journals requesting inclusion that meet the National Library of Medicine's (USA) guidelines are included.

Although we have reliably reported the publications that we did retrieve, we cannot be certain that we have retrieved all relevant publications. MEDLARS contains over 19 million entries and we must trust that the National Library of Medicine's PUBMED search engine thoroughly searches the archive.

We believe our quantity survey is accurate because the manual work involved in the MEDLARS retrievals was cross-verified between the Canadian counts and world-wide counts and the search algorithms required were applied systematically with a minimal alteration in search parameters. Manual counting was unnecessary, as MEDLARS provided a count with each retrieval. The principal source of human error is the initial MEDLARS coding of publications upon archiving. In a previous study we found the affiliation coding process to have an error ratio of $1: 2100(0.05 \%) .{ }^{1}$

It is possible to retrieve from MEDLARS each author's contributions, or those of all authors within a given institutional department. Thus it is feasible that a survey could be made of the contributions of all Canadian anesthesiologists, if desired. We have not endeavoured to do so because the task would be arduous and too difficult to replicate thereby leaving its results suspect. We recognize that it could be useful to know, for example, the number of anesthesiologists that have never published, the average number of publications among those that do publish, or whether most anesthesiologists are now part of multidisciplinary research teams that publish in non-anesthesiology journals. However, to use MEDLARS to find these numbers would involve scrutinizing each retrieval list while retrieving an uncertain number of strategic variants (e.g., On., Ont., Ontario, Ontario-Canada, NOT Ontario-California, and NOT Ont.-California). Ours was a much simpler process since we used only the global counts.

The determination that only $28.7 \%$ of Canadian anesthesiology publications occur in the anesthesiology journals ( $18.1 \%$ world wide) should be viewed with the consideration that 34 search terms in a single pass were required to obtain the result. We cannot confirm that the search engine functioned correctly, however, we did repeat the search with the terms re-arranged and obtained the same results.

Other investigators have attempted to make comparisons between institutions and journals by measuring 
research output in terms of quantity, quality, or the ratio of quality to quantity (i.e., impact factors). ${ }^{2-4}$ Each method is flawed. Quantities can be inflated by subdividing and/or substantively duplicating reports. If citation counts are used, these can be inflated by self-citation, author bias, counting methodology, or continued citation of retracted articles. ${ }^{5-7}$ Quality surveys, being subjective, are likely to be more heavily biassed than quantity surveys. We have attempted to have an unbiased census, which is why columns in the included tables are not summed. Since many publications can be categorized to more than one topic within a given table, rather than adjudicate which topic was primary (in order to establish a single count), we counted all categories. Thus, a table grand sum does not correctly represent the total number of publications comprising the table, but a table grand average does correctly represent the average number of publications for a single table topic.

In common usage, any census supplements decisions where need and merit are not obviously apparent. In this regard, our MEDLARS counts may be broadly useful since there is little inherent bias in the counts. We have not employed any weighting strategies, for example, a contribution in a pediatric physiology journal is not counted differently from a contribution in an anesthesia journal. Instead, we have based our counts on the anesthesiology topics defined by the National Library of Medicine's MESH subcommittees. Our counts may also be beneficial in providing medical students, residents, and fellows an awareness of the research trends in this field.

\section{References}

l Gagnon RE, Macnab AJ, Gagnon FA A quantitative ranking of Canada's research output of original human studies for the decade 1989 to 1998. CMAJ 2000; 162: $37-40$.

2 Garfield $E$. Which medical journals have the greatest impact? Ann Intern Med 1986; 105: 313-20.

3 Garfield E. How can impact factors be improved? BMJ 1996; 313: 411-3.

4 Larson JS, Kershaw $R$ Rating journals in health care administration by the textbook citation method. Med Care 1993; 31: 1057-61.

5 Comphell FM. National bias: a comparison of citation practices by health professionals. Bull Med Libr Assoc 1990; 78: 376-82.

6 Gallagher EJ, Barnaby DP. Evidence of methodologic bias in the derivation of the science citation index impact factor. Ann Emerg Med 1998; 31: 83-6.

7 Budd JM, Siepert M, Schultz TR. Phenomena of retraction. Reasons for retraction and citations to the publications. JAMA 1998; 280: 296-7. 